\title{
Correction to: Water Hauling and Girls' School Attendance: Some New Evidence from Ghana
}

\author{
Céline Nauges ${ }^{1,2}$
}

Published online: 20 November 2017

(C) Springer Science+Business Media B.V., part of Springer Nature 2017

\section{Correction to: Environ Resource Econ (2017) 66:65-88 https://doi.org/10.1007/s10640-015-9938-5}

After publication of this article (Nauges and Strand, 2017) we have agreed that the name of Jon Strand should be removed because his contribution to the article was regarded by him as insufficient to warrant a listing as a co-author.

As indicated by Ethics Reporting, the authorship on the original article remains the same, and the authorship on the erratum is the new version.

The original article can be found online at https://doi.org/10.1007/s10640-015-9938-5.

\section{Céline Nauges}

celine.nauges@toulouse.inra.fr

1 Toulouse School of Economics (INRA-LERNA), Toulouse, France

2 School of Economics, The University of Queensland, Brisbane, Australia 